\title{
Epidermal growth factor receptor in breast carcinoma: association between gene copy number and mutations
}

Ning $L v^{1,2}$, Xiaoming Xie ${ }^{1,2}$, Qidong Ge $e^{1,2}$, Suxia Lin ${ }^{2,3}$, Xi Wang ${ }^{1,2}$, Yanan Kong ${ }^{1,2}$, Hongliu Shi ${ }^{1,2}$, Xinhua Xie $e^{1,2}$ and Weidong Wei $\mathrm{i}^{1,2^{*}}$

\begin{abstract}
Background: The epidermal growth factor receptor (EGFR) is an available target of effective anti-EGFR therapy for human breast cancer. The aim of this study was to assess the presence of EGFR gene amplification and mutations in breast cancer and to analyze the association between the statuses of these two gene alterations.

Materials and methods: EGFR gene amplification and mutations were investigated in formalin-fixed, paraffinembedded tissues from 139 Chinese female patients with breast cancer by means of fluorescence in-situ hybridization (FISH) and fluorescently labeled real-time quantitative polymerase chain reaction (RT-PCR), respectively.

Results: EGFR gene amplification was observed in 46/139 (33.1\%) of cases by FISH. Based on RT-PCR, 2/139 (1.4\%) samples had EGFR gene mutations. Overall, only $1(0.7 \%)$ of the cases was identified with both whole gene amplification and mutation, and 92 (66.2\%) of cases were negative for both. High gene copy numbers of EGFR had significant correlation with the occurrence of EGFR protein expressions $(P=0.002)$.

Conclusion: In this study, EGFR mutations were presented in only two samples, indicating that EGFR mutations should not be employed in future trials with anti-EGFR therapies for breast cancer. However, EGFR whole gene amplification is frequently observed in patients with breast cancer. It will be of significant interest to investigate whether EGFR gene copy number is a suitable screening test for EGFR-targeted therapy for breast cancer.
\end{abstract}

Keywords: breast cancer, epidermal growth factor receptor, EGFR, FISH, gene amplification, gene mutation, realtime PCR.

\section{Introduction}

The human epidermal growth factor receptor (HER/ EGFR/ErbB) family of receptor tyrosine kinases is comprised of four transmembrane growth factor receptor proteins that share similarities in structure and function. The epidermal growth factor receptor (HER-1/EGFR/ ErbB1), encoded by the gene located on the short arm of chromosome 7, is a member of this family of Type I transmembrane tyrosine kinase receptors. EGFR is a 170 $\mathrm{kDa}$ transmembrane protein consisting of an intracellular domain (tyrosine kinase domain), a short

\footnotetext{
* Correspondence: weiweid@mail.sysu.edu.cn

'Department of Breast Oncology, Sun Yat-Sen University Cancer Center,

Guangzhou, Guangdong 510060, P. R. China

Full list of author information is available at the end of the article
}

transmembrane and juxtamembrane domain, and an extracellular domain (ligand-binding domain) with ligand-activated tyrosine kinase activity [1]. EGFR can be activated by various growth factor ligands, including epidermal growth factor (EGF) and the transforming growth factor-alpha (TGF- $\alpha$ ). Ligand binding to EGFR results in homo- or hetero-dimerization of EGFR with another EGFR molecule or a different member of the ErbB family (e.g., HER2). This is followed by phosphorylation of the tyrosine kinase residue, which in turn induces the actual downstream signaling cascade [2-4]. Ligand-dependent activation of the EGFR tyrosine kinase residues serve as binding sites of signal transducer and activator proteins that mediate the downstream signaling processes of intracellular substrates [5]. The 
phosphatidyl inositol 3' kinase (PI3K) and Akt pathway and Ras/MAPK pathway are major signaling mechanisms, and they function in the control of several important biologic processes, including cell proliferation, survival, angiogenesis, and migration as well as resistance to apoptosis [6-8].

Due to the biologic significance of EGFR molecular signaling in carcinomas, several monoclonal antibodies against the ligand-binding domain of EGFR and small molecule tyrosine kinase inhibitors of the tyrosine kinase domain of EGFR have been investigated in the therapy of malignant tumors (e.g., non-small cell lung cancer [NSCLC], colorectal cancer [CRC] and metastatic breast cancer [MBC]) [9-16]. It is important to study whether EGFR is overexpressed in patients with breast cancer since these patients can be given specific EGFR molecule tyrosine kinase inhibitors such as gefitinib and lapatinib $[15,16]$. There are only a few reports regarding the overexpression of EGFR, with these studies indicating $8-36 \%$ of breast cancers over express this protein. However, systematic studies appraising EGFR gene amplification and mutations in the same set of cases among Chinese female patients with breast cancer are absent [17-19]. Many studies have concentrated on lung cancers, where most patients ultimately have a relapse. Mechanisms involved in resistance to targeted inhibition of lung cancer include secondary resistance mutations, inactivation of PTEN, activation of the MET pathway, minor clones with KRAS mutations, and adenocarcinoma transformation [20-32]. However, the mechanism of drug resistance in breast cancer is unknown.

The purpose of the present study was to examine 139 formalin-fixed, paraffin-embedded specimens from Chinese female patients with breast cancer, with a particular focus on the presence of EGFR gene amplification and mutations. We attempted to explore the relationship between EGFR copy numbers and EGFR mutations. We also analyzed the correlation between EGFR gene status and HER2 protein, estrogen receptor (ER), progesterone receptor (PR), and cytokeratin 5/6 (CK5/6) expression as well as $\mathrm{Ki}-67$ index proliferation and intrinsic subtypes in these cases. In this study, we analyzed EGFR gene copy numbers by fluorescence in-situ hybridization (FISH), and the mutations were analyzed using a real-time (RT)-PCR detection kit.

\section{Methods and Materials Patient Information}

One hundred and thirty-nine Chinese female patients with breast cancer who underwent surgery at the Department of Breast Oncology, Sun Yat-Sen University Cancer Center, from Jan 2010 to May 2011 were selected. The cases with primary breast cancer were randomly selected from the archives of our Department of
Pathology based on the availability of blocks and sufficient tissues. Additionally, only cases with available EGFR FISH results, mutational status, and immunostaining were analyzed. Clinical information included age, disease stage, tumor type, mass size, and axillary lymph node metastasis status. The age interval of the patients was 25-75 years, with a mean of 50.8 years. The TNM Cancer Staging Manual 7th edition of the American Joint Committee on Cancer (AJCC) [33] was used to classify the cancer staging: stage 0, 2 cases; stage I, 28 cases; stage II, 78 cases; stage III, 30 cases; and stage IV, 1 case. Using immunohistochemistry as a surrogate definition of intrinsic subtypes for expression profiling, cases that were ER and/or PR positive, HER2 negative, and Ki-67 low $(<14 \%)$ were classified as luminal A cancers; cases that were ER and/or PR positive, HER2 negative, and Ki-67 high were classified as luminal B (HER2 positive) cancers; cases that were ER and/or PR positive, any $\mathrm{Ki}-67$, and HER2 overexpressed or amplified were classified as luminal B (HER2 positive); cases that were HER2 overexpressed or amplified and ER and PR absent were classified as HER2 positive (non-luminal) cancers; cases that were ER and PR absent, HER2 negative, and CK5/6 and/or EGFR positive were classified as basal-like cancers; and cases that lacked expression of ER, PR, HER2, CK5/6, and EGFR were considered unclassified [34-36]. The histopathological classification of breast cancer in these cases was performed by an experienced pathologist of our pathology department. Ethics approval was obtained from the Ethical Review Committee of Sun Yat-Sen University Cancer Center, and informed consent was obtained from all patients.

\section{Tissue Preparation}

Tissue microarrays were constructed using $0.6-\mathrm{mm}$ tissue cores as previously described [37]. One core from the central and the other from the peripheral part of the tumor were sampled for each tumor. For each case, 4-5 $\mu \mathrm{m}$ sections of formalin-fixed and paraffin-embedded tissues were stained with Hematoxylin and Eosin for the establishment of the histopathological tumor type and differentiation grade.

\section{Fluorescence In-Situ Hybridization Analysis of EGFR Gene Copy Number}

FISH analysis for EGFR gene copy number was performed according to the manufacturer's protocol using the GLP EGFR/CSP 7 probe (GP Medical Technologies, Beijing, China). Simply, the tissue microarray sections were incubated at $65^{\circ} \mathrm{C}$ overnight. The slides were deparaffinized in dimethyl benzene at room temperature for 10 minutes and dehydrated in 100\% ethanol. After incubation in $30 \%$ sodium bisulfite at $50^{\circ} \mathrm{C}$ for $20-30$ minutes, the sections were incubated in $2 \times$ saline 
sodium citrate buffer $(2 \times \mathrm{SSC} ; \mathrm{pH} 7.0)$ at $75^{\circ} \mathrm{C}$ for 5 minutes. The smears were digested with proteinase $\mathrm{K}$ $(0.20 \mathrm{mg} / \mathrm{ml}$ in $2 \times \mathrm{SSC}$; $\mathrm{pH} 7.0)$ for $20-30$ minutes at $37^{\circ} \mathrm{C}$, followed by a rinse in $2 \times \mathrm{SSC}$ at room temperature for 5 minutes and then dehydration in $70 \%, 85 \%$, and $100 \%$ ethanol solutions in sequence. The solvents were changed frequently and regularly so that all traces of residual paraffin were removed in the above processes [38]. After amplification of the GLP EGFR/CSP 7 probe set, the slide was covered with a coverslip and sealed with Indian rubber. The slides were heated at $80^{\circ} \mathrm{C}$ for 8-10 minutes and were then hybridized at $42^{\circ} \mathrm{C}$ overnight. After a post-hybridization wash and dehydration of the samples, 4', 6'-diamidino-2-phenylindole (DAPI) was applied for chromatin counterstaining. At least 100 nuclei were scored for both EGFR gene signals and chromosome 7 signals under a magnification of 1000x.

The ratio was defined as: the total number of red signals (EGFR copy number) divided by the number of green signals (chromosome 7 copy number) in 100 nuclei. Tumors were scored as EGFR amplified when the EGFR FISH-positive results were: a) ratio $\geq 2.0$, b) $\geq 15$ copies of the red signals per cell in $\geq 10 \%$ of total cells, or c) the presence of EGFR gene clusters; or scored as EGFR polysomy when: ratio $<2.0$, but $\geq 40 \%$ of cells display $\geq 4$ copies. Meanwhile, EGFR FISH-negative include disomy ( $\geq 90 \%$ of cells display $\leq 2$ copies), low trisomy ( $\geq 40 \%$ of cells display $\leq 2$ copies, $10-40 \%$ of cells display 3 copies, and $<10 \%$ of cells display $\geq 4$ copies), high trisomy ( $\geq 40 \%$ of cells display $\leq 2$ copies, $\geq 40 \%$ of cells display 3 copies, and $<10 \%$ of cells display $\geq 4$ copies), and low polysomy (10-40\% of cells display $\geq 4$ copies) [38-40]. Healthy cells were used as controls.

\section{Fluorescent PCR Method for Analysis of EGFR Gene Mutations}

The 5- $\mu \mathrm{m}$ formalin-fixed and paraffin-embedded tissues were assayed for the presence of the most common EGFR mutations in exon 19 (E746-A750 and L747P753insS short in-frame deletions) and exon 21 (L858R and L861Q point mutations) using a RT-PCR detection kit with the Taqman probe technique (GP Medical Technologies, Beijing, China). Genomic DNA was extracted from tissues using a TIANamp Genomic DNA kit (Tiangen Biotech, Beijing, China). Two of the exon 19 deletions and the exon 21 mutations of the EGFR gene were analyzed using fluorescently labeled RT-PCR products.

Amplification reactions were setup using reagents included in the Real Time PCR Detection Kit (GP Medical Technologies, Beijing, China), in accordance with the manufacturer's protocol. Essentially, the exon 19 PCR reaction consisted of 5.4 ul deionized water, 7.5 ul $2 \times$ PCR pre-mix, 0.15 ul forward primers-1, 0.15 ul reverse primers-1, 0.15 ul probe-1 (delE746-A750), and 0.15 ul probe-2 (delL747-P753insS) in a total volume of $13.5 \mathrm{ul}$. The exon 21 PCR reaction consisted of 5.3 ul deionized water, 7.5 ul $2 \times$ PCR pre-mix, 0.15 ul forward primers2, 0.15 ul reverse primers-2, 0.2 ul probe-3 (L858R), and $0.2 \mathrm{ul}$ probe-4 (L861Q) in a total volume of $13.5 \mathrm{ul}$. The PCR cycling program was as follows: $50^{\circ} \mathrm{C}$ for $2 \mathrm{~min}$, $95^{\circ} \mathrm{C}$ for $10 \mathrm{~min}$, and 40 cycles of $95^{\circ} \mathrm{C}$ for $15 \mathrm{sec}, 62^{\circ} \mathrm{C}$ for $1 \mathrm{~min}$. PCR analysis was performed by using an ABI Prism 7500 Real-Time PCR equipment (Applied Biosystems, Foster City, CA, USA) as previously described $[41,42]$.

\section{Immunohistochemistry of EGFR Protein Expression}

Immunohistochemical staining for EGFR was performed on the 5 - $\mu \mathrm{m}$ formalin-fixed, paraffin-embedded tissue slide. EGFR was stained using the pharmDx kit according to manufacturer's instructions (DAKO). EGFR was scored positive if any membranous tumor cell staining was observed, whether or not it was completely circumferential. Staining intensity was scored as follows: 0, no membrane staining; $1+$, weak staining intensity; $2+$, moderate staining intensity; $3+$, strong staining intensity. The staining intensity was multiplied by the percentage of tumor cells be stained to obtain a total score, resulting in a possible range 0 to 300. Samples with an overall score of 200 and higher were considered positive for EGFR-overexpression.

\section{Statistical analysis}

SPSS version 13.0 software (SPSS, Chicago, IL, USA) was used to analyze the data. Associations between EGFR gene amplification and protein expression were evaluated using Pearson's chi-square test with cross tables. Differences of $\mathrm{P}<0.05$ were considered significant. Pearson's Chi-squared test or Fisher's exact test was also applied for evaluation of multiple comparisons between EGFR amplification and expression and age, disease stage, tumor type, axillary lymph node metastasis status, and immunohistochemical index (i.e., ER, PR, and HER2). A $P$ value $<0.05$ was considered statistically significant.

\section{Results}

\section{EGFR Gene Copy Numbers in Breast Carcinomas}

We obtained both FISH and RT-PCR EGFR data on 139 female patients with breast cancer. A total of 48 (34.5\%) of the 139 tumors presented EGFR disomy, 6 tumors (4.3\%) presented low trisomy, 3 tumors (2.2\%) presented high trisomy, 36 (25.9\%) tumors presented low polysomy, 42 tumors (30.2\%) presented high polysomy, and 4 tumors $(2.9 \%)$ presented amplification. From the total of 139 tumors, 46 (33.1\%) presented positivity with FISH; 93 (66.9\%) did not demonstrate EGFR gene amplification (Figure 1). 

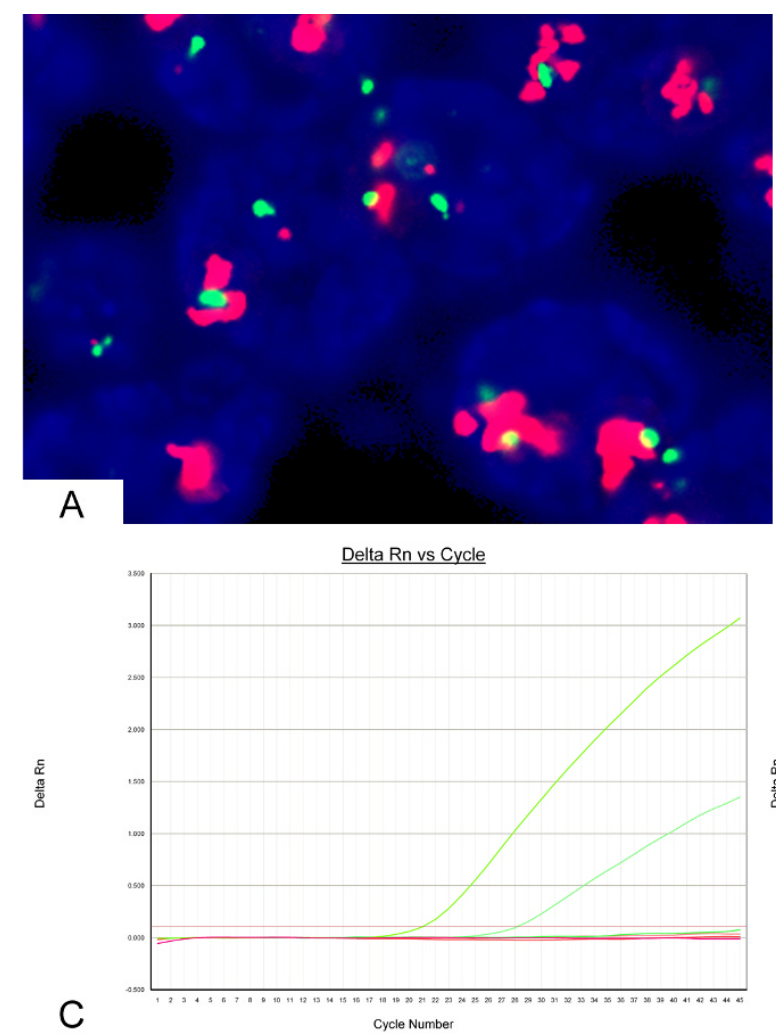

Figure 1 Analysis of EGFR gene amplification and mutations based on FISH and RT-PCR analysis. A: FISH positive (amplification), B: FISH negative (low trisomy), C: mutation positive (the left ascending curve represents the positive control, the right ascending curve represents the exon 21 L858R mutation), D: mutation negative (the ascending curve represents the positive control).
Delta Rn vs Cycle

$\mathrm{D}$

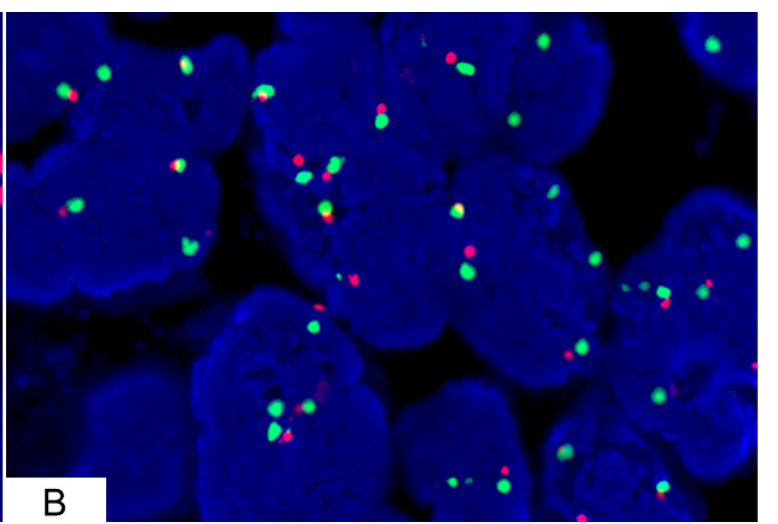

\section{EGFR Gene Mutations in Breast Carcinomas}

A total of $2(1.4 \%)$ of the 139 tumors harbored EGFR mutations, which include 1 exon 19 deletion with low trisomy of the EGFR gene copy number and 1 exon 21 L858R mutation with high polysomy of the EGFR gene copy number. None of the cases presented both of these mutations. Overall, one tumor was poorly prognostic triple-negative moderate-grade invasive ductal carcinoma; the other was also a moderate-grade invasive ductal carcinoma and ER positive. Both of the patients were postmenopausal with pathological stage IIA and negative for axillary lymph node metastasis.

\section{EGFR Protein Expression in Breast Carcinomas}

Based on immunohistochemistry, twenty-five (18.0\%) of the 139 cases had an immunohistochemical score of 200 or more; the remaining $114(82.0 \%)$ cases showed a negative result (Figure 2).

\section{Association between the EGFR and Clinical and \\ Pathologic Features}

The clinical and pathological features of all cases were evaluated for the purpose of determining clinically relevant

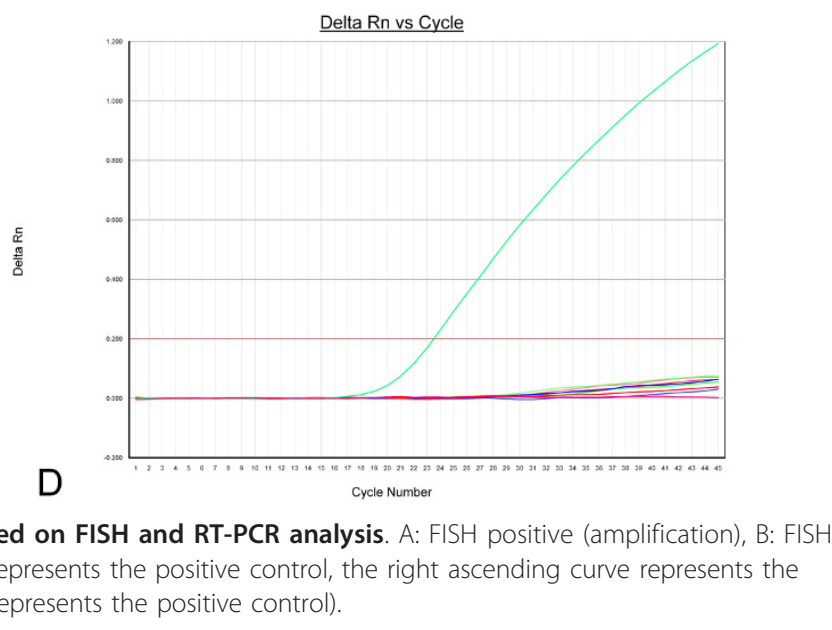

correlations. EGFR gene copy number was associated with Ki-67 proliferation index ( $\mathrm{P}=0.007)$. EGFR FISH positivity was not associated with clinical-pathological features, including age $(\mathrm{P}=0.265)$, lymph node metastasis $(\mathrm{P}=$ $0.765)$, disease stage $(\mathrm{P}=0.748)$, tumor type $(\mathrm{P}=0.551)$, ER status $(\mathrm{P}=0.464)$, $\mathrm{PR}$ status $(\mathrm{P}=0.943)$, and HER2 status $(\mathrm{P}=0.733)$. The invasive ductal carcinomas group showed a trend toward higher EGFR gene amplification, although the association with tumor type was not statistically significant. EGFR protein expression was associated with molecular subtypes (luminal subtypes vs. others, $\mathrm{P}=$ $0.010)$, grade (II vs. III, $\mathrm{P}=0.001)$, ER $(\mathrm{P}=0.002)$, and PR $(\mathrm{P}<0.001)$, respectively (Table 1$)$.

\section{Association of EGFR Protein Expression and EGFR Gene Amplification}

15 of the 46 breast carcinomas with EGFR FISH positivity showed immunohistochemical positive scores and 31 cases had negative results. There was a correlation between protein overexpression and gene amplification, the FISH-positive rate was significantly higher in the IHC-positive group than in the IHC-negative group ( $\mathrm{P}=$ 0.002) (Table 2). 


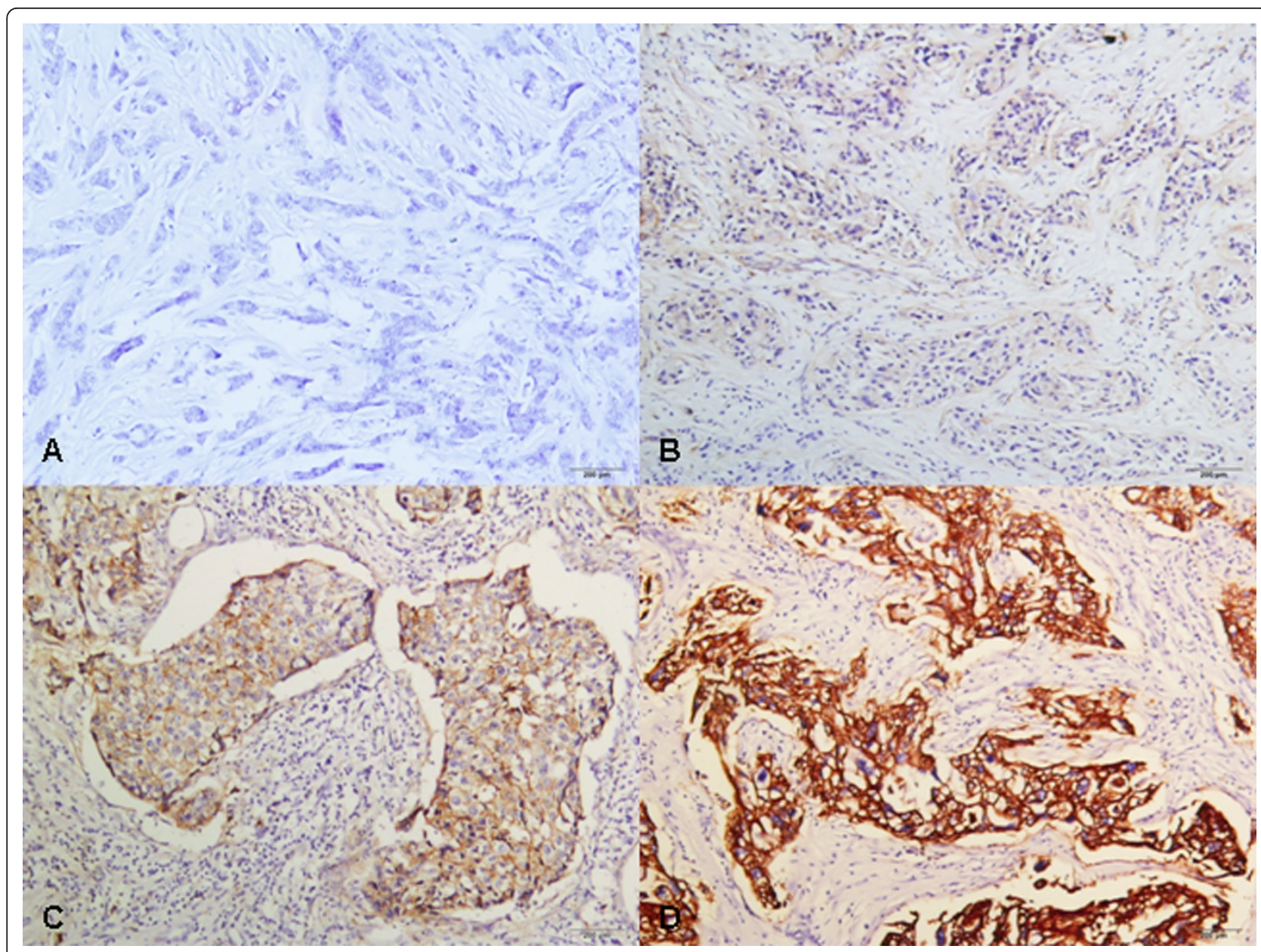

Figure 2 EGFR protein expression by immunohistochemistry. A: Negative EGFR expression; B: 1+ EGFR expression; C: 2+ EGFR expression; D: 3+ EGFR expression.

\section{Discussion}

The aim of this study was to evaluate the frequency of EGFR gene amplification and mutations in 139 female patients with breast cancer. It is known that EGFR gene amplification indicates EGF-sensitive breast cancer. In one study, EGFR gene amplification and/or high EGFR expression were demonstrated as biological predictors of poor prognosis in breast carcinoma [43]. Due to the availability and benefit of anti-EGFR therapies, including both monoclonal antibodies (MoAbs) and small molecule tyrosine kinase inhibitors (TKI), for the treatment of various solid malignant tumors, such as non-small cell lung cancer (NSCLC), squamous cell carcinoma of the head and neck (HNSCC), and colorectal cancer $(\mathrm{CRC})$, the role of EGFR gene status has been investigated in a number of clinical studies. Several data sets regarding EGFR gene amplification in breast cancer are accessible. In various trials, EGFR gene amplification in breast carcinomas was different, ranging between 0.8-28 percent. Khawla Al-Kuraya et al. [44] described EGFR gene amplification in $0.8 \%$ of studied tumors, Jungsil Ro et al. [43] reported positivity in 3 of the 21 evaluable cases, Rohit Bhargava et al. [45] found positive EGFR amplification in 11/175 (6\%) of samples, Christian Kersting et al. [46] showed EGFR whole gene amplification in $4.7 \%$ of investigated cases, and in the cohorts of Judith A. Gilbert et al. [47] and Jorge S Reis-Filho et al. [48] $26 \%$ and $28 \%$ of the metastatic breast carcinomas displayed high EGFR copy number, respectively. It is likely that multiple techniques and scoring systems used in the detection of EGFR amplification have led to the inconsistent outcomes of these different trials.

In this current study we used FISH to detect EGFR gene copy numbers in breast carcinomas. We identified EGFR gene amplification in 46 (33.1\%) of the 139 patients with breast cancer. This percentage is higher than the range reported by the studies mentioned above. It seems that the Chinese origin of the specimens, possibly in addition to the use of various techniques and scoring criteria, may possibly have contributed to the 
Table 1 Summary of the relationship between EGFR copy number, expression, and the patients' clinical-pathological characteristics

\begin{tabular}{|c|c|c|c|c|c|c|}
\hline \multirow{2}{*}{$\begin{array}{c}\text { clinical- } \\
\text { pathological characteristic }\end{array}$} & \multicolumn{3}{|c|}{ Copy number } & \multicolumn{3}{|c|}{ Expression } \\
\hline & Positive, N/\% & Negative, N/\% & $P$ value & Positive, N/\% & Negative, N/\% & $P$ value \\
\hline \multicolumn{7}{|l|}{ Age(years) } \\
\hline$\leq 35$ & $5 / 10.9$ & $4 / 4.3$ & $0.265^{c}$ & $23 / 92.0$ & 107/93.9 & $1.000^{c}$ \\
\hline$>35$ & $41 / 89.1$ & $89 / 95.7$ & & $2 / 8.0$ & $7 / 6.1$ & \\
\hline \multicolumn{7}{|l|}{ Lymph node metastasis } \\
\hline Positive & $23 / 50$ & $49 / 52.7$ & $0.765^{a}$ & $16 / 64.0$ & $56 / 49.1$ & $0.178^{\mathrm{a}}$ \\
\hline Negative & $23 / 50$ & $44 / 47.3$ & & $9 / 36.0$ & $58 / 50.9$ & \\
\hline \multicolumn{7}{|l|}{ Stage } \\
\hline 0 & $0 / 0$ & $2 / 2.2$ & $0.748^{\mathrm{a}, \$}$ & $1 / 4.0$ & $2 / 1.8$ & $0.450^{\mathrm{a}, ~} \$$ \\
\hline । & $10 / 21.7$ & $18 / 19.4$ & & $6 / 24.0$ & $21 / 18.4$ & \\
\hline$\|$ & $25 / 54.3$ & $53 / 57$ & & $11 / 44.0$ & $67 / 58.8$ & \\
\hline III & $10 / 21.7$ & $20 / 21.5$ & & $7 / 28.0$ & $22 / 20.2$ & \\
\hline IV & $1 / 2.2$ & $0 / 0$ & & $0 / 0$ & $1 / 0.9$ & \\
\hline \multicolumn{7}{|l|}{ Tumor type } \\
\hline DCIS & $0 / 0$ & $3 / 3.2$ & $0.551^{b, \&}$ & $1 / 4.0$ & $2 / 1.8$ & $1.000^{c, \&}$ \\
\hline LCIS & $0 / 0$ & $0 / 0$ & & $0 / 0$ & $0 / 0$ & \\
\hline IDC & $44 / 95.7$ & $83 / 89.2$ & & $23 / 92.0$ & $104 / 91.2$ & \\
\hline ILC & 0/0 & $3 / 3.2$ & & 0/0 & $3 / 2.6$ & \\
\hline Other & $2 / 4.3$ & $4 / 4.3$ & & $1 / 4.0$ & $5 / 4.4$ & \\
\hline \multicolumn{7}{|l|}{ ER } \\
\hline Positive & $33 / 71.7$ & $72 / 77.4$ & $0.464^{\mathrm{a}}$ & $13 / 52.0$ & $92 / 80.7$ & $0.002^{\mathrm{a}}$ \\
\hline Negative & $13 / 28.3$ & $21 / 22.6$ & & $12 / 48.0$ & $22 / 19.3$ & \\
\hline \multicolumn{7}{|l|}{$P R$} \\
\hline Positive & $27 / 58.7$ & $54 / 58.1$ & $0.943^{\mathrm{a}}$ & $5 / 20.0$ & $76 / 66.7$ & $0.000^{\mathrm{a}}$ \\
\hline Negative & $19 / 41.3$ & $39 / 41.9$ & & $20 / 80.0$ & $38 / 33.3$ & \\
\hline \multicolumn{7}{|l|}{ HER2 } \\
\hline Positive & 9/19.6 & $16 / 17.2$ & $0.733^{\mathrm{a}}$ & $5 / 20.0$ & $29 / 25.4$ & $0.567^{a}$ \\
\hline Negative & $37 / 80.4$ & $77 / 82.8$ & & $20 / 80.0$ & $85 / 74.6$ & \\
\hline \multicolumn{7}{|l|}{ Ki-67 (\%) } \\
\hline$<14$ & $7 / 15.2$ & $35 / 37.6$ & $0.007^{\mathrm{a}}$ & $17 / 68.0$ & $67 / 58.8$ & $0.393^{a}$ \\
\hline$>16$ & $39 / 84.8$ & $58 / 62.4$ & & $8 / 32.0$ & $47 / 41.2$ & \\
\hline \multicolumn{7}{|l|}{ Subtypes } \\
\hline LUMA & 9/19.6 & $28 / 30.1$ & $0.628^{\mathrm{a}}, \wedge$ & $4 / 16.0$ & $33 / 28.9$ & $0.010^{c}, \wedge$ \\
\hline LUMB (HER2-NEG) & $17 / 37.0$ & $32 / 34.4$ & & $7 / 28.0$ & $42 / 36.8$ & \\
\hline LUMB (HER2-POS) & $10 / 21.7$ & $16 / 17.2$ & & $4 / 16.0$ & $22 / 19.3$ & \\
\hline HER2 & $2 / 4.3$ & $6 / 17.2$ & & $1 / 4.0$ & $7 / 6.1$ & \\
\hline Basal-like & $6 / 13.0$ & $4 / 4.3$ & & $9 / 36.0$ & $1 / 0.9$ & \\
\hline UC & $2 / 4.3$ & $7 / 7.5$ & & $0 / 0$ & $9 / 7.9$ & \\
\hline \multicolumn{7}{|l|}{ Grade } \\
\hline । & $0 / 0$ & $0 / 0$ & $0.921^{\mathrm{a}, ~ \#}$ & $0 / 0$ & $0 / 0$ & $0.001^{\mathrm{a}, ~ \#}$ \\
\hline$\|$ & $31 / 67.4$ & $52 / 55.9$ & & $10 / 40.0$ & $73 / 64.0$ & \\
\hline III & $12 / 26.1$ & $21 / 22.6$ & & $13 / 52.0$ & $20 / 17.5$ & \\
\hline UC & $3 / 6.5$ & $20 / 21.5$ & & 2/8.0 & $21 / 18.4$ & \\
\hline
\end{tabular}

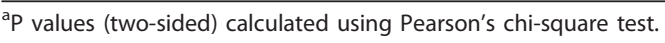

${ }^{\mathrm{b}} \mathrm{P}$ values (two-sided) calculated using Fisher's exact test.

${ }^{c} \mathrm{P}$ values (two-sided) calculated using Continuity Correction of Pearson's chi-square test.

\$Pearson's chi-square test for stage 0-II and III- IV vs. EGFR status.

\&Fisher's exact test for invasive ductal carcinoma and other types vs. EGFR status.

$\wedge$ Pearson's chi-square test for luminal subtypes and other subtypes vs. EGFR status.

\#Grade II and III vs. EGFR status.

DCIS, ductal carcinoma in-situ; LCIS, lobular carcinoma in-situ; IDC, invasive ductal carcinoma; ILC, invasive lobular carcinoma; ER, estrogen receptor; PR, progesterone receptor; HER2, human epidermal growth factor receptor-2; Ki-67, Ki-67 proliferation index; LUMA, luminal A; LUMB (HER2-NEG), luminal B (HER2negative); LUMB (HER2-POS), luminal B (HER2-positive); UC, unclassified. 
Table 2 Correlation of EGFR gene amplification and protein expression

\begin{tabular}{cccc}
\hline \multirow{2}{*}{ Expression } & \multicolumn{2}{c}{ Amplification } & P value \\
\cline { 2 - 4 } & Positive & Negative & \\
\hline Positive & $15 / 32.6$ & $10 / 10.8$ & $0.002^{\$}$ \\
Negative & $31 / 67.4$ & $83 / 89.2$ & \\
\hline
\end{tabular}

$\$ \mathrm{P}$ values (two-sided) calculated using Pearson's chi-square test.

difference in the results. In this study, 46 carcinomas showed EGFR gene amplification, which include 42 tumors (30.2\%) presenting high polysomy and 4 tumors (2.9\%) presenting amplification (based on the ratio of EGFR gene copies to CEP7 gene copies in at least 100 tumor cell nuclei). These data revealed that EGFR gene amplification is a frequent event in Chinese patients with breast carcinomas. As observed from this study, EGFR positive immunostaining was consistent with EGFR gene amplification. It appears that positive EGFR protein overexpression could predict gene amplification in breast cancers.

Activation of EGFR involves heterodimerization of EGFR with HER2. Our results showed that there was no correlation between EGFR and HER2 protein expression $(\mathrm{P}=0.567)$, which might indicated that activated EGFR can form heterodimer not only with HER2, but also with other members of ErbB family.

Currently, many trials have assayed for EGFR gene amplification in order to identify patients that would benefit from anti-EGFR therapy. Patients with EGFR gene amplification have been connected to poor prognosis in HNSCC $[49,50]$ and NSCLC [51]. However, patients with EGFR mutations have demonstrated an increased benefit as compared to patients having EGFR amplification [39]. EGFR gene mutations indicate sensitivity to gefitinib, and it was demonstrated that about $85 \%$ of patients with NSCLC who obtained benefit from gefitinib treatment were found to have mutations in exons 18 to 21 of the tyrosine kinase domain of the EGFR gene [51-54]. EGFR mutations in exon 19 (short in-frame deletions) or 21 L858R (point mutation) affect the adenosine triphosphate (ATP) pocket of the tyrosine kinase domain leading to the activation of 4-anilinoquinazoline compounds, which function to compete with ATP [53]. Anti-EGFR therapy can consequently lead to the downregulation of downstream signaling cascades, such as the PI3K/Akt, RAS/Erk, MAPK, and STAT pathways, responsible for cell proliferation and survival, resulting in the inhibition of cell proliferation and induction of cell apoptosis, respectively. The method for EGFR-mutations used in this study can detect the most common mutations of exons 19 and 21, but there are still other mutations of exons 19 and 21 that cannot be detected. Additionally, mutations of exons 18 and 20, which can harbor upto 15\% of EGFR-mutations in lung cancer, cannot be analyzed in this way.

It is reported in some studies that EGFR gene mutations in the tyrosine kinase domain in patients with lung cancer are accompanied with a low increase in EGFR gene copy number $[55,56]$. However, in this study, EGFR gene mutations could be identified in only 2 out of 139 cases $(1.4 \%)$ of the breast carcinoma samples, confirming that EGFR gene mutations are rare in Chinese patients. Further trials with large samples and/ or different methods are highly recommended to be performed to validate the observations mentioned above.

\section{Conclusions}

We observed that EGFR gene mutations were rare in breast carcinomas, but EGFR gene amplification was detected in about one third of the cases in this population. In this study, rare mutations in the EGFR gene in patients with breast cancer were detected, indicating that EGFR gene mutations are infrequent in this cohort of breast cancers. This suggested that EGFR mutation analysis is not useful as a screening test for sensitivity to anti-EGFR therapy for breast cancers. Nevertheless, further studies will be required to investigate whether EGFR gene copy number is a suitable screening test for EGFR targeted therapy.

\section{Abbreviations \\ ATP: adenosine triphosphate; CK5/6: cytokeratin 5/6; CRC: colorectal cancer; DAPI: 4': 6'-diamidino-2-phenylindole; EGFR: epidermal growth factor receptor; ER: estrogen receptor; FISH: fluorescence in-situ hybridization; HER2: human epidermal growth factor receptor-2; HNSCC: squamous cell carcinoma of the head and neck; MBC: metastatic breast cancer; MoAbs: monoclonal antibodies; NSCLC: non-small cell lung cancer; PI3K: phosphatidyl inositol 3'-kinase; PR: progesterone receptor; Real Time PCR: Real-time quantitative Polymerase Chain Reaction; SSC: saline sodium citrate buffer; TGF-a: transforming growth factor-alpha; TKI: tyrosine kinase inhibitors.}

\section{Acknowledgements}

We thank Tao Tang and Qiong Shao for their excellent technical assistance with mutation analysis and FISH analysis.

\section{Author details}

${ }^{1}$ Department of Breast Oncology, Sun Yat-Sen University Cancer Center, Guangzhou, Guangdong 510060, P. R. China. ${ }^{2}$ State Key Laboratory of Oncology in South China, Guangzhou, Guangdong 510060, P. R. China. ${ }^{3}$ Department of Pathology, Sun Yat-Sen University Cancer Center, Guangzhou, Guangdong 510060, P. R. China.

\section{Authors' contributions}

WDW conceived and designed the study, WDW and NL performed the experiments, WDW and NL conducted the statistical analysis, and WDW and $\mathrm{NL}$ drafted the manuscript with substantial contributions from all authors. All authors read and approved the final manuscript.

\section{Competing interests}

The authors declare that they have no competing interests.

Received: 14 July 2011 Accepted: 2 December 2011

Published: 2 December 2011 


\section{References}

1. Cohen S, Ushiro H, Stoscheck C, Chinkers M: A native 170, 000 epiderma growth factor receptor-kinase complex from shed plasma membrane vesicles. J Biol Chem 1982, 257:1523-1531.

2. McCune BK, Earp HS: The epidermal growth factor receptor tyrosine kinase in liver epithelial cells. The effect of ligand-dependent changes in cellular location. J Biol Chem 1989, 264:15501-15507.

3. Garrett TP, McKern NM, Lou M, Elleman TC, Adams TE, Lovrecz GO, Zhu HJ, Walker F, Frenkel MJ, Hoyne PA, et al: Crystal structure of a truncated epidermal growth factor receptor extracellular domain bound to transforming growth factor alpha. Cell 2002, 110:763-773.

4. Ogiso H, Ishitani R, Nureki O, Fukai S, Yamanaka M, Kim JH, Saito K, Sakamoto A, Inoue M, Shirouzu M, Yokoyama S: Crystal structure of the complex of human epidermal growth factor and receptor extracellular domains. Cell 2002, 110:775-787.

5. Vivanco I, Sawyers CL: The phosphatidylinositol 3-Kinase AKT pathway in human cancer. Nat Rev Cancer 2002, 2:489-501.

6. Chan TO, Rittenhouse SE, Tsichlis PN: AKT/PKB and other D3 phosphoinositide-regulated kinases: kinase activation by phosphoinositide-dependent phosphorylation. Annu Rev Biochem 1999. 68:965-1014

7. Batzer AG, Rotin D, Urena JM, Skolnik EY, Schlessinger J: Hierarchy of binding sites for Grb2 and Shc on the epidermal growth factor receptor. Mol Cell Biol 1994, 14:5192-5201.

8. Lowenstein EJ, Daly RJ, Batzer AG, Li W, Margolis B, Lammers R, Ullrich A, Skolnik EY, Bar-Sagi D, Schlessinger J: The SH2 and SH3 domaincontaining protein GRB2 links receptor tyrosine kinases to ras signaling. Cell 1992, 70:431-442.

9. Ciardiello F, Tortora G: EGFR antagonists in cancer treatment. N Engl J Med 2008, 358:1160-1174.

10. Dutta PR, Maity A: Cellular responses to EGFR inhibitors and their relevance to cancer therapy. Cancer Lett 2007, 254:165-177.

11. Tsutsui S, Ohno S, Murakami S, Hachitanda Y, Oda S: Prognostic value of epidermal growth factor receptor (EGFR) and its relationship to the estrogen receptor status in 1029 patients with breast cancer. Breast Cancer Res Treat 2002, 71:67-75.

12. Burris HA, Hurwitz HI, Dees EC, Dowlati A, Blackwell KL, $\mathrm{O}^{\prime}$ Neil $B$, Marcom PK, Ellis MJ, Overmoyer B, Jones SF, et al: Phase I safety, pharmacokinetics, and clinical activity study of lapatinib (GW572016), a reversible dual inhibitor of epidermal growth factor receptor tyrosine kinases, in heavily pretreated patients with metastatic carcinomas. J Clin Oncol 2005, 23:5305-5313.

13. Spector NL, Xia W, Burris H, Hurwitz H, Dees EC, Dowlati A, O'Neil B, Overmoyer B, Marcom PK, Blackwell KL, et al: Study of the biologic effects of lapatinib, a reversible inhibitor of ErbB1 and ErbB2 tyrosine kinases, on tumor growth and survival pathways in patients with advanced malignancies. J Clin Oncol 2005, 23:2502-2512.

14. Twelves C, Trigo JM, Jones R, De Rosa F, Rakhit A, Fettner S, Wright T, Baselga J: Erlotinib in combination with capecitabine and docetaxel in patients with metastatic breast cancer: a dose-escalation study. Eur J Cancer 2008, 44:419-426.

15. Ciardiello F, Troiani T, Caputo F, De Laurentiis M, Tortora G, Palmieri G, De Vita F, Diadema MR, Orditura M, Colantuoni G, et al: Phase II study of gefitinib in combination with docetaxel as first-line therapy in metastatic breast cancer. Br J Cancer 2006, 94:1604-1609.

16. Baselga J, Albanell J, Ruiz A, Lluch A, Gascon P, Guillem V, Gonzalez S, Sauleda S, Marimon I, Tabernero JM, et al: Phase II and tumor pharmacodynamic study of gefitinib in patients with advanced breast cancer. J Clin Oncol 2005, 23:5323-5333.

17. Tsutsui S, Kataoka A, Ohno S, Murakami S, Kinoshita J, Hachitanda Y: Prognostic and predictive value of epidermal growth factor receptor in recurrent breast cancer. Clin Cancer Res 2002, 8:3454-3460.

18. Tsuda H, Morita D, Kimura M, Shinto E, Ohtsuka Y, Matsubara O, Inazawa J, Tamaki K, Mochizuki H, Tamai S, Hiraide H: Correlation of KIT and EGFR overexpression with invasive ductal breast carcinoma of the solidtubular subtype, nuclear grade 3 , and mesenchymal or myoepithelial differentiation. Cancer Sci 2005, 96:48-53.

19. Walker RA, Dearing SJ: Expression of epidermal growth factor receptor mRNA and protein in primary breast carcinomas. Breast Cancer Res Trea 1999, 53:167-176.
20. Kobayashi S, Boggon TJ, Dayaram T, Janne PA, Kocher O, Meyerson M, Johnson BE, Eck MJ, Tenen DG, Halmos B: EGFR mutation and resistance of non-small-cell lung cancer to gefitinib. N Engl J Med 2005, 352:786-792.

21. Pao W, Miller VA, Politi KA, Riely GJ, Somwar R, Zakowski MF, Kris MG, Varmus $\mathrm{H}$ : Acquired resistance of lung adenocarcinomas to gefitinib or erlotinib is associated with a second mutation in the EGFR kinase domain. PLoS Med 2005, 2:e73.

22. Yatabe Y: EGFR mutations and the terminal respiratory unit. Cancer Metastasis Rev 2010, 29:23-36.

23. Kosaka T, Yatabe Y, Endoh H, Yoshida K, Hida T, Tsuboi M, Tada H, Kuwano H, Mitsudomi T: Analysis of epidermal growth factor receptor gene mutation in patients with non-small cell lung cancer and acquired resistance to gefitinib. Clin Cancer Res 2006, 12:5764-5769.

24. Balak MN, Gong Y, Riely GJ, Somwar R, Li AR, Zakowski MF, Chiang A Yang G, Ouerfelli O, Kris MG, et al: Novel D761Y and common secondary T790M mutations in epidermal growth factor receptor-mutant lung adenocarcinomas with acquired resistance to kinase inhibitors. Clin Cancer Res 2006, 12:6494-6501.

25. Bean J, Riely GJ, Balak M, Marks JL, Ladanyi M, Miller VA, Pao W: Acquired resistance to epidermal growth factor receptor kinase inhibitors associated with a novel T854A mutation in a patient with EGFR-mutant lung adenocarcinoma. Clin Cancer Res 2008, 14:7519-7525.

26. Engelman JA, Mukohara T, Zejnullahu K, Lifshits E, Borras AM, Gale CM, Naumov GN, Yeap BY, Jarrell E, Sun J, et al: Allelic dilution obscures detection of a biologically significant resistance mutation in EGFRamplified lung cancer. J Clin Invest 2006, 116:2695-2706.

27. Yano S, Wang W, Li Q, Matsumoto K, Sakurama H, Nakamura T, Ogino H, Kakiuchi S, Hanibuchi M, Nishioka Y, et al: Hepatocyte growth factor induces gefitinib resistance of lung adenocarcinoma with epidermal growth factor receptor-activating mutations. Cancer Res 2008, 68:9479-9487.

28. Sos ML, Koker M, Weir BA, Heynck S, Rabinovsky R, Zander T, Seeger JM, Weiss J, Fischer F, Frommolt P, et al: PTEN loss contributes to erlotinib resistance in EGFR-mutant lung cancer by activation of Akt and EGFR. Cancer Res 2009, 69:3256-3261.

29. Marchetti A, Milella M, Felicioni L, Cappuzzo F, Irtelli L, Del Grammastro M, Sciarrotta M, Malatesta S, Nuzzo C, Finocchiaro G, et al: Clinical implications of KRAS mutations in lung cancer patients treated with tyrosine kinase inhibitors: an important role for mutations in minor clones. Neoplasia 2009, 11:1084-1092.

30. Tatematsu A, Shimizu J, Murakami Y, Horio Y, Nakamura S, Hida T Mitsudomi T, Yatabe Y: Epidermal growth factor receptor mutations in small cell lung cancer. Clin Cancer Res 2008, 14:6092-6096.

31. Zakowski MF, Ladanyi M, Kris MG: EGFR mutations in small-cell lung cancers in patients who have never smoked. N Engl J Med 2006 355:213-215

32. Okamoto I, Araki J, Suto R, Shimada M, Nakagawa K, Fukuoka M: EGFR mutation in gefitinib-responsive small-cell lung cancer. Ann Oncol 2006, 17:1028-1029.

33. Sinn HP, Helmchen $B$, Wittekind $C H$ : [TNM classification of breast cancer: changes and comments on the 7th edition]. Pathologe 2010, 31:361-366

34. Goldhirsch A, Wood WC, Coates AS, Gelber RD, Thurlimann B, Senn HJ: Strategies for subtypes-dealing with the diversity of breast cancer: highlights of the St Gallen International Expert Consensus on the Primary Therapy of Early Breast Cancer 2011. Ann Oncol 22:1736-1747.

35. Tamimi RM, Baer HJ, Marotti J, Galan M, Galaburda L, Fu Y, Deitz AC, Connolly JL, Schnitt SJ, Colditz GA, Collins LC: Comparison of molecular phenotypes of ductal carcinoma in situ and invasive breast cancer. Breast Cancer Res 2008, 10:R67.

36. Cheang MC, Voduc D, Bajdik C, Leung S, McKinney S, Chia SK, Perou CM, Nielsen TO: Basal-like breast cancer defined by five biomarkers has superior prognostic value than triple-negative phenotype. Clin Cancer Res 2008, 14:1368-1376.

37. Kononen J, Bubendorf L, Kallioniemi A, Barlund M, Schraml P, Leighton S, Torhorst J, Mihatsch MJ, Sauter G, Kallioniemi OP: Tissue microarrays for high-throughput molecular profiling of tumor specimens. Nat Med 1998, 4:844-847.

38. Varella-Garcia M, Diebold J, Eberhard DA, Geenen K, Hirschmann A Kockx M, Nagelmeier I, Ruschoff J, Schmitt M, Arbogast S, Cappuzzo F: EGFR fluorescence in situ hybridisation assay: guidelines for application to non-small-cell lung cancer. J Clin Pathol 2009, 62:970-977. 
39. Cappuzzo F, Hirsch FR, Rossi E, Bartolini S, Ceresoli GL, Bemis L, Haney J, Witta S, Danenberg K, Domenichini I, et al: Epidermal growth factor receptor gene and protein and gefitinib sensitivity in non-small-cell lung cancer. J Natl Cancer Inst 2005, 97:643-655.

40. Hirsch FR, Varella-Garcia M, Bunn PA Jr, Di Maria MV, Veve R, Bremmes RM, Baron AE, Zeng C, Franklin WA: Epidermal growth factor receptor in nonsmall-cell lung carcinomas: correlation between gene copy number and protein expression and impact on prognosis. J Clin Oncol 2003, 21:3798-3807.

41. Toyama T, Yamashita H, Kondo N, Okuda K, Takahashi S, Sasaki H, Sugiura $H$, Iwase $H$, Fujii $Y$ : Frequently increased epidermal growth factor receptor (EGFR) copy numbers and decreased BRCA1 mRNA expression in Japanese triple-negative breast cancers. BMC Cancer 2008, 8:309.

42. Endo K, Konishi A, Sasaki H, Takada M, Tanaka H, Okumura M, Kawahara M, Sugiura H, Kuwabara Y, Fukai l, et al: Epidermal growth factor receptor gene mutation in non-small cell lung cancer using highly sensitive and fast TaqMan PCR assay. Lung Cancer 2005, 50:375-384.

43. Ro J, North SM, Gallick GE, Hortobagyi GN, Gutterman JU, Blick M: Amplified and overexpressed epidermal growth factor receptor gene in uncultured primary human breast carcinoma. Cancer Res 1988, 48:161-164.

44. Al-Kuraya K, Schraml P, Torhorst J, Tapia C, Zaharieva B, Novotny H, Spichtin H, Maurer R, Mirlacher M, Kochli O, et al: Prognostic relevance of gene amplifications and coamplifications in breast cancer. Cancer Res 2004, 64:8534-8540.

45. Bhargava R, Gerald WL, Li AR, Pan Q, Lal P, Ladanyi M, Chen B: EGFR gene amplification in breast cancer: correlation with epidermal growth factor receptor mRNA and protein expression and HER-2 status and absence of EGFR-activating mutations. Mod Pathol 2005, 18:1027-1033.

46. Kersting C, Tidow N, Schmidt H, Liedtke C, Neumann J, Boecker W, van Diest PJ, Brandt B, Buerger H: Gene dosage PCR and fluorescence in situ hybridization reveal low frequency of egfr amplifications despite protein overexpression in invasive breast carcinoma. Lab Invest 2004, 84:582-587.

47. Gilbert JA, Goetz MP, Reynolds CA, Ingle JN, Giordano KF, Suman VJ, Blair HE, Jenkins RB, Lingle WL, Reinholz MM, et al: Molecular analysis of metaplastic breast carcinoma: high EGFR copy number via aneusomy. Mol Cancer Ther 2008, 7:944-951.

48. Reis-Filho JS, Milanezi F, Carvalho S, Simpson PT, Steele D, Savage K, Lambros MB, Pereira EM, Nesland JM, Lakhani SR, Schmitt FC: Metaplastic breast carcinomas exhibit EGFR, but not HER2, gene amplification and overexpression: immunohistochemical and chromogenic in situ hybridization analysis. Breast Cancer Res 2005, 7:R1028-1035.

49. Chung CH, Ely K, McGavran L, Varella-Garcia M, Parker J, Parker N, Jarrett C, Carter J, Murphy BA, Netterville J, et al: Increased epidermal growth factor receptor gene copy number is associated with poor prognosis in head and neck squamous cell carcinomas. J Clin Oncol 2006, 24:4170-4176.

50. Temam S, Kawaguchi H, El-Naggar AK, Jelinek J, Tang H, Liu DD, Lang W, Issa JP, Lee JJ, Mao L: Epidermal growth factor receptor copy number alterations correlate with poor clinical outcome in patients with head and neck squamous cancer. J Clin Oncol 2007, 25:2164-2170.

51. Sequist LV, Joshi VA, Janne PA, Muzikansky A, Fidias P, Meyerson M, Haber DA, Kucherlapati R, Johnson BE, Lynch TJ: Response to treatment and survival of patients with non-small cell lung cancer undergoing somatic EGFR mutation testing. Oncologist 2007, 12:90-98.

52. Lynch TJ, Bell DW, Sordella R, Gurubhagavatula S, Okimoto RA, Brannigan BW, Harris PL, Haserlat SM, Supko JG, Haluska FG, et al: Activating mutations in the epidermal growth factor receptor underlying responsiveness of non-small-cell lung cancer to gefitinib. $N$ Engl J Med 2004, 350:2129-2139.

53. Paez JG, Janne PA, Lee JC, Tracy S, Greulich H, Gabriel S, Herman P, Kaye FJ, Lindeman N, Boggon TJ, et al: EGFR mutations in lung cancer: correlation with clinical response to gefitinib therapy. Science 2004, 304:1497-1500.

54. Pao W, Miller V, Zakowski M, Doherty J, Politi K, Sarkaria I, Singh B, Heelan R, Rusch $V$, Fulton $L$, et al: EGF receptor gene mutations are common in lung cancers from "never smokers" and are associated with sensitivity of tumors to gefitinib and erlotinib. Proc Natl Acad Sci USA 2004, 101:13306-13311.

55. Amann J, Kalyankrishna S, Massion PP, Ohm JE, Girard L, Shigematsu H, Peyton M, Juroske D, Huang Y, Stuart Salmon J, et al: Aberrant epidermal growth factor receptor signaling and enhanced sensitivity to EGFR inhibitors in lung cancer. Cancer Res 2005, 65:226-235.
56. Kosaka T, Yatabe Y, Endoh H, Kuwano H, Takahashi T, Mitsudomi T: Mutations of the epidermal growth factor receptor gene in lung cancer: biological and clinical implications. Cancer Res 2004, 64:8919-8923.

doi:10.1186/1746-1596-6-118

Cite this article as: Lv et al.: Epidermal growth factor receptor in breast carcinoma: association between gene copy number and mutations. Diagnostic Pathology 2011 6:118.

\section{Submit your next manuscript to BioMed Central and take full advantage of:}

- Convenient online submission

- Thorough peer review

- No space constraints or color figure charges

- Immediate publication on acceptance

- Inclusion in PubMed, CAS, Scopus and Google Scholar

- Research which is freely available for redistribution

Submit your manuscript at www.biomedcentral.com/submit
Ciomed Central 